\title{
The Relevance of the Social Control Theory in Explaining Crime among African Americans
}

\author{
Ayodeji Daramola ${ }^{1} \&$ Gbolahan Solomon Osho ${ }^{2, *}$ \\ ${ }^{1}$ College of Juvenile Justice and Psychology, Prairie View A \& M University, Texas, USA \\ ${ }^{2}$ Dept. of Management and Marketing, Prairie A\&M University, Texas, USA \\ *Corresponding author: Dept. of Management and Marketing, Prairie A\&M University, \\ Texas, USA. Tel: 1-936-261-9280 E-mail: gsosho@ pvamu.edu
}

Received: February 16, 2017 Accepted: March 2, 2017 Published: April 7, 2017

doi:10.5296/jsr.v8i1.10729 URL: https://doi.org/10.5296jsr.v8i1.10729

\begin{abstract}
Today, criminologists, especially, Black criminologists, are thoroughly perplexed by the same problem of disproportionate minority confinement (DMC) most especially of Blacks in both the juvenile and criminal justice systems. Are African Americans more criminally minded than other races or ethnic groups? Do African Americans actually commit more crimes than others? These are the questions that the different deviant theories have tried to answer. The concept of social bonding arose from social control theory, which suggests that attachment to family and school, commitment to conventional pathways of achievements and beliefs in the legitimacy of social order are primary and important elements of establishing a social bond (Hirschi, 1969). In expounding his social control theory, Hirschi listed the elements of the bond as attachment, commitment, involvement, and belief. Does it mean that African Americans commit more crimes than other racial and ethnic groups? Or are African Americans genetically wired to be criminogenic? Is the society or the environment to blame for the perceived higher rate of crime among African Americans? Or are the criminal justice system, the judicial system, and the juvenile justice system, all together racially biased against Blacks, especially, Black males? Even though Hirschi (1969) did not mention attachment to religious beliefs as part of social control, but for the African American families, the church could play a significant role in helping to cement the bond of adolescents to their families. Any study of the African American family is not complete without the church. According to Work (1900), in all social study of the Negro, the church must be considered, for it is one of the greatest factors in his social life.
\end{abstract}

Keywords: crime, family: attachment, commitment, involvement, deviant theories, social and control theory 


\section{Introduction}

Early Black criminologists like W. B Du Bois, M. Work, and E. F. Frazier, at different time periods and using different methods, all tried to explain crime among African Americans. Although they had different reasons why African American committed crime, one thread that was common in their studies was that Blacks were overrepresented in the criminal justice system. Du Bois believed that the overrepresentation of Blacks in the criminal justice system was due to the convict-lease system, the racial bias of the courts, the lawlessness and barbarity of the mobs, and segregation. Frazier, in trying to explain crime among African Americans, viewed the family and other community institutions as the church, as agents of social control. As far as M. Work was concerned, the administration of justice was an important theme of his studies. Today, criminologists, especially, Black criminologists, are thoroughly perplexed by the same problem of disproportionate minority confinement (DMC) most especially of Blacks in both the juvenile and criminal justice systems. Are African Americans more criminally minded than other races or ethnic groups? Do African Americans actually commit more crimes than others? These are the questions that the different deviant theories have tried to answer.

Even though no one theory could fully explain juvenile delinquency, the social control theory, for which Hirschi (1969) is well respected, is still relevant today about 40 years after he propounded the theory. For several years, the strain/anomie theory as expounded by Merton, Sellin, and others, held sway in the 1960s until Hirschi came out in 1969 with his social control theory. While many sociologists and criminologists had always believed that family dynamics had something to do with delinquency, it was Hirschi who first actually synthesized the interrelationship that family, school, and peers have on juvenile delinquency. Actually, Hirschi was not trying to explain the causes of crime; rather, he was trying to explain why some people do not commit crime.

In deducing his theory, Hirschi was of the view that individuals have bonds that bind them to others one way or the other, and that if the bond is weak or broken, there is the likelihood that such individuals might engage in deviant behaviors. He called the social interconnection elements of the bond. He divided the elements of the bond into four categories: (1) Attachment, (2) Commitment, (3) Involvement, and (4) Beliefs. Research has shown that individuals who have better attachment to families that are good role models tend to be less involved in deviant behaviors than those who have no such attachment. Given that attachment to parents is usually the first type of attachment that most people first experience in life, a more stable and attached parents help their children to learn to form that attachment early in life. But when there is no such attachment within the family itself, individuals in such families might have problems forging a lasting bond with others, and thus may engage in deviant behaviors.

Many people obey the laws of the land because of a fear of the consequences of breaking the laws: hence, some weigh the costs and the risks involved in engaging in deviant behaviors because of their commitment to the norms of the society. This is so true in the pursuit of educational and occupational careers. Having spent so many years to build a successful career 
or in pursuit of educational goals, some people will think twice before jeopardizing all they had worked for over the years. Such individuals tend to avoid behaviors that might destroy their careers for life. In a way, they are committed to the laws that promote the greater good of the society.

Also, research has shown that involvement in conventional activities helps to keep some youth on the straight path because they can find something to do in their idle time. An idle person could become an unwilling tool of the devil. That is why many afterschool programs have been found to be effective in reducing juvenile delinquency due to the fact that the youth have something to occupy their time instead of just roaming around doing nothing or doing something that might get them into trouble.

The last element of social bonding mentioned by Hirschi (1969) is belief. The social control theory assumes the existence of common value system within the society or group whose norms are violated. The human conscience is so endowed with an inner witness that whispers to our soul when we do something wrong. Humans have this innate ability to know right from wrong. Virtually every society has its own set of beliefs that members of the society are supposed to believe, respect, and keep. Those who adhere to the beliefs of their society will probably not engage in deviant behaviors like those who do not adhere to such beliefs even though they believe them. Even though Hirschi did not mention the role that religious beliefs play in his social control theory, Work, the African American criminologist, mentioned the important role that the church played in the lives of African Americans. In studying the causes of crime among African Americans, Work believed that the church could not and should not be divorced from such studies.

\section{Literature Review}

Research has shown that adolescents who form a positive affiliation or social bond with their school are more likely than adolescents who fail to establish this social bond to engage in a variety of prosocial behaviors and achieve up to their potential academically, and less likely to engage in problem behaviors such as fighting, bullying, truancy, vandalism, substance abuse, and other delinquent behaviors (Simons-Morton, B. G., A. D. Crump., D. L. Haynie., and K. E. Saylor, 1999). The concept of social bonding arose from social control theory, which suggests that attachment to family and school, commitment to conventional pathways of achievements and beliefs in the legitimacy of social order are primary and important elements of establishing a social bond (Hirschi, 1969). In expounding his social control theory, Hirschi listed the elements of the bond as attachment, commitment, involvement, and belief.

Also, the theory and some empirical data suggest that social bonding is protective against anti-social behavior (Hawkins \& Weis, 1985; Kumpfer \& Turner, 1991; McBride et al., 1995). Similarly, bonding to school, conceptualized by Hawkins and Weis (1985), includes attachment to prosocial peers, commitment to conventional academic and social activities at school, and belief in the established norms for school behavior. Student-school bonding can 
be advanced by developing social skills and social competence, improving school climate, and encouraging authoritative parenting practices (Perry \& Jessor, 1984; Hawkins \& Catalano, 1990; Schaps \& Battistich, 1991). The literature about school includes a variety of definitions for school connectedness. Some researchers study school engagement while others examine school attachment, and others analyze school bonding. The various terms have created an overlapping and confusing definitional spectrum.

Like school attachment, school bonding represents an umbrella term to encompass several aspects of a student's relationship to school. According to Polk et al., (1981), Thornberry, T., M. Moore., and R. L. Christenson, 1985) and Siegel and Senna (1988:302), research has shown that school failure is a stronger predictor of delinquency than socioeconomic status, race or ethnic background, and peer relations. Another factor that facilitates psychological well-being is the adolescent's attachment to school. Research indicates that a student's sense of belonging at school is positively associated with academic motivation and social competence and negatively correlated with psychological distress and classroom misbehaviors (Pianta \& Nimetz, 1991; Goodenow \& Grady, 1993; Wentzel, 1997). Attachment to school has been found to reduce the overall frequency of problem behaviors among adolescents. In addition, such attachment to school could also decrease the prevalence of deviant behaviors as well as reduce the intensity (Dornbusch, S. M., K. G. Erickson., J. Laird., and C. A. Wong, 2001).

Moreover, school climate has been found to have an important influence on school bonding (Pyper, J. R., H. J. Freiberg., M. Ginsburg., and D. W. Spuck, 1987). Students are motivated by an authoritative teaching style that is demanding, supportive and fair (Hawkins et al., 1988; Schaps and Battistich, 1991; Olweus, 1993). Students, who like their classes, believe that their teachers are supportive and fair, have good peer relations, accept their school's mission, values and standards, are more likely to bond to school. Student-school bonding may be improved by defining in positive ways the culture and personality of the school, establishing school policies and practices that are relevant and fair, and increasing opportunities for students to participate in school activities (Gottfredson, 1986). Participation in academic and co-curricular activities increases bonding because students are reinforced by their own success experiences and enjoy the opportunity to affiliate with peers and teachers who share their interests (Hawkins \& Weis, 1985).

In addition, children are likely to place a value on their academic and behavioral performance at school that is equal to the interest and concern demonstrated by their parents (Steinberg, 1993; Paulson, 1994). Parents can be encouraged to establish high expectations, become highly involved in their children's school life, and support academic achievement and school participation (Baumrind, 1991; Dornbusch, 1994). Given the abundance of research that support the views that school bonding is a predictor of juvenile delinquency, how does school bonding or the failure thereof explain delinquency among minority students, especially African Americans?

According to Rosenaum and Lasley (1990:493), paralleling the "gender gap" that characterizes the school-delinquency literature, there is also a "racial gap"---a failure to 
examine racial variation in the impact of school factors on juvenile misconduct. In fact, the research literature is surprisingly silent in general on the issue of racial differences in delinquency. Matsueda and Heimer (1987:826) suggest that three factors are primarily responsible for this lack of attention: the politically sensitive nature of examining racial differences in crime and delinquency; the belief that racial differences in official measures of crime and delinquency do not reflect real differences, but rather are the result of criminal justice system bias; and the difficulty of measuring delinquency and its correlates reliably because of racial differences in the validity of self-report data.

Thus, regardless of the reasons underlying it, this neglect of African Americans in delinquency research is challenged both by more general literature on black adolescence and by a number of empirical realities that suggest that there are important racial differences in schooling, differences that may in turn, result in differential levels of delinquency involvement such as the higher drop-out rate of black compared with white adolescents; charges of racially biased testing, classification, and tracking; negative teacher attitudes toward black students and lower teacher expectations for black than for white students (Ogbu, 1988:177), and the pejorative label of "acting white" by peers of those black students who are successful in school (Fordham \& Ogbu, 1986).

Therefore, the considerable ambivalence among blacks regarding the role of education in their lives similarly belies the neglect of race in the school-delinquency equation. While many blacks view the American educational system as the embodiment of the culture's false promise of equality and therefore withhold any serious commitment, there are many blacks who see it as a means to greater opportunity and an improved social and economic future---as the only means by which they can acquire the skills necessary to compete with whites (Liska \& Reed, 1985, 557-558).

However, Ogbu (1988:170-181) has noted that while education is valued among blacks, several realities mitigate against their commitment to educational achievement: a "job ceiling" that restricts the employment of blacks, regardless of their level of education; socialization and life experiences that reinforce the reality of this job ceiling and create considerable disillusionment about the merit of expending effort on academic pursuits; and an objectively inferior education which prohibits blacks from competing for more desirable jobs and blocks significant social mobility. Ironically, the response of many blacks to these realities may further increase the likelihood of school failure: disillusionment and alienation; withdrawal of commitment to educational activities that are perceived as having no payoffs; the use of "survival strategies" (nonconventional economic activities) that are incompatible with middle-class classroom behavior; and a general attitude of suspicion, distrust, and hostility toward the school system. To the extent that black youth adopt such a frame of reference early in their lives, they enter school with certain predispositions that inhibit commitment to school and that result in a greater probability of experiencing school difficulties.

Thus, there is considerable evidence suggesting that blacks experience school in a qualitatively different way than whites (McAdoo, 1988a, 1988b; McAdoo \& McAdoo, 1985). To the extent that school factors are predictive of delinquency involvement as previous 
research has shown that they are, at least for white male students, such variation in school experiences may well be reflected in differential delinquent outcomes. As Jessor (1982) contends, early involvement in deviant activities may block future participation in educational and occupational pursuits. According to Clayton and Voss (1981:164), whites may be better able than blacks to flirt with deviant behavior in adolescence without suffering long-term deleterious effects.

According to Hirschi (1969), a delinquent is someone who experiences school failure. Lack of attachment to parents and teachers and a weak commitment to educational and occupational goals are potential risk factors for school failure and involvement in delinquency. Youth who do not care what their teachers think about them, who do not care about making good grades in school, who do not care about spending much time in doing homework, who do not have any aspirations for the future, and who generally do not want to be in school - these are the youth who are the most likely candidates for delinquency (Cernkovich \& Giordano, 1992). From a social control perspective, the lack of school bonding is a critical link in the causal chain leading to delinquency involvement (Rosenbaum \& Lasley, 1990:497).

However, even though the racial composition of a school affects all students to some degree, it tends to affect black students more than others because of the distinct educational experiences that they have had in this country. The fact that for centuries, educational pursuit and success had been the exclusive preserve of whites, many black students have an ambivalent view about educational success, believing that blacks are not given the same educational opportunities as white students, and that the few blacks who succeed academically are not adequately rewarded. Thus, academic success places a particularly onerous stigma on the black male; his manhood is questioned by the suspicion that he might be gay (Cernkovich \& Giordano, 1992).

Consequently, because academic success threatens the black identity on both a cultural and individual level, academic achievement is opposed socially by the peer group and psychologically by the individual. On a social level, the peer group discourages educational striving by negative labeling, exclusion, or even physical assault. On a personal level, individuals resist educational striving out of fear of such responses and to avoid psychological dissonance (Fordham \& Ogbu, 1986). Black youth adapt differently to the academic success dilemma.

Underachievers avoid conflict altogether by limiting academic efforts. On the other hand, achievers minimize negative labeling by using a variety of mechanisms such as pretending to be someone who does not expend much effort to earn good grades, choosing bullies as friends or protectors in exchange for help with schoolwork, and maintaining a low profile by not joining academic clubs or by cutting classes. These and other mechanisms allow black students to succeed in school without incurring the wrath of their peers (Fordham, 1988; Fordham \& Ogbu, (1988).

According to Hirschi (1969), family, school, and peers are the three major agents of social control in the society. Family structures are different today, not just because of the high rate 
of divorce and complex stepfamilies, but also due to the increasing rates of nonmarital childbearing and cohabitation. More than one half of children will spend some time in a single-parent family (McLanahan \& Sandefur, 1994). Research on the relationship between family structure and delinquency is not new. Shaw and McKay (1932) evaluated the significance of "broken homes" in juvenile delinquency. In a critical analysis of the previous studies of Slawson (1926) and Burt (1925) that had reported almost twice the rate of broken homes among institutionalized (or delinquent) youth versus noninstitutionalized (or nondelinquent), Shaw and McKay (1932) argued that the importance of broken homes per se as a causative factor in juvenile delinquency was overstated and unclear (Demuth \& Brown, 2004).

However, Nye (1958) in a study of the familial factors on delinquent behavior in an individual-level analysis of noninstitutionalized boys and girls argued that family structure did not exact a direct effect on adolescent delinquency but, rather, an indirect effect through the social controls provided by family relationships. Also, he found that children from homes with a single parent exhibited higher levels of delinquency, which he argued resulted primarily from a loss of direct parental controls and decreased child-parent attachments.

But more recent research consistently reveals that children from broken homes are more delinquent than those from intact families (Gove \& Crutchfield, 1982; Lamborn, S. D., N. S. Mounts., L. Steinberg., and S. M. Dornbusch, 1991; Rankin \& Kern, 1994). Even then some researchers believe that the effects of family structure are largely mediated by family processes, such as parental monitoring, supervision, and closeness (Van Voorhis, P., F. T. Cullen., R. A. Mathers., and C. C. Garner, 1988). In fact, Cernkovich and Giordano (1987); Laub and Sampson (1988); and Van Voorhis et al. (1988), all found no significant effect of family structure on delinquency; rather, variation in juvenile delinquency is explained by indicators of parent-child attachment and home quality. For example, children who experience low levels of parental control and supervision are at a greater risk of delinquent behavior (Nye, 1958). Still, strong attachment to two parents has been found to provide a greater protective effect against delinquency than strong attachment to only one parent (Rankin \& Kern, 1994).

\section{Meta-Analysis}

Several studies have been done to test the social control theory with regard to family, school, and peers, to see if there is any correlation between the three and delinquency. For example, Cernkovich and Giordano (1992) used the social control theory to see how school bonding affects delinquency, focusing in particular on the role of the school in the delinquent involvement of black youths. Using data from the 1980 census, and 942 face-to-face interviews

to test the social control theory, Cernkovich and Giordano found that African Americans were at least as strongly bonded to school as whites. 


\section{Macrothink}

The literature examining the link between family structure and delinquency has tended to focus on the attachment component of social control theory (Nye, 1958; Biron and LeBlanc, 1977; Gove and Crutchfield, 1982, Johnson, 1986; Cernkovich and Giordiano, 1987). But, few contemporary researchers believe that family structure is directly related to delinquent behavior (Wells and Rankin, 1986; Goetting, 1994; Chen and Kaplan, 1997). Instead, they suggest that familial disruption is associated with juvenile delinquency because it influences a variety of different parent child interaction variables (Kierkus and Baer, 2002). Some criminologists have suggested that parental attachment may explain why children from non-traditional family structures are more likely to engage in delinquent behavior (Nye, 1958; Biron and LeBlanc, 1977; Gove and Crutchfield, 1986; Cernkovich and Giordiano, 1987). They have hypothesized that non-traditional families are likely to be deficient in how well they can provide this aspect of social control.

For example, Nye (1958) believed that single parents were not able to supervise their children as well as two parent families. He also argued that disrupted families were characterized by greater conflict and unhappiness than their intact counterparts and reasoned that these factors would undermine affective relationships within the family and interfere with intimate communication network. This reasoning was extended by other researchers (Chapman, 1991). Contemporary authors have pointed out that adolescents typically report less intimacy and closeness with step-parents than with biological parents (Furstenberg, 1987) and that step-parents are frequently unable to monitor effectively and supervise their adolescent children (Hetherington, 1987). Families that contain a biological father and a step-mother appear to be particularly deficient in these respects (White, Brinkerhoff, and Booth, 1985).

Biron and LeBlanc (1977) conducted an early study that provided empirical support for the notion that parental attachment might represent an intervening variable between family structure and delinquency. Their analysis revealed that the structural aspects of family living were significantly related to home-based delinquent behavior even after age and sex had been controlled. Similarly, Goldstein (1984) determined that father absence was significantly related to police contact and school discipline for several groups of young people, notwithstanding the applications of controls for race and socioeconomic status.

Sampson and Laub (1994) further suggest that most structural aspects of family life are not directly associated with delinquency. They found that the addition of three key family process variables (discipline, maternal supervision, and parent-child attachment) into multivariate regression models tended to negate most of the significant correlations between the structural indicators of family life and delinquent behavior. Adlaf and Ivis (1997) arrived at similar conclusion: they showed that familial disruption was significantly correlated with four substance abuse measures and a composite delinquency scale. When a number of demographic and family quality variables were entered into a multivariate regression equation, family structure remained a significant predictor of only one of the five outcome measures.

Unfortunately, these studies cannot be considered definitive because each raises at least one important methodological issue. The Sampson and Laub (1994) study was based on a 
half-century old data set with limited generalizability. Goldstein's (1984) work was based exclusively on official report statistics. Biron and LeBlanc (1977) examined only home-based delinquent behavior and used a small, single city sample. Adlaf and Ivis (1997) did not differentiate between different types of delinquency in their study (Kierkus \& Baer, 2002).

\section{Conclusion}

The problematic issue of disproportionate minority confinement (DMC) is probably the most pertinent aspect of both the juvenile and criminal justice systems that has forced criminologists, especially, black criminologists, to reappraise the different deviant theories as they relate to crime among African Americans. Does it mean that African Americans commit more crimes than other racial and ethnic groups? Or are African Americans genetically wired to be criminogenic? Is the society or the environment to blame for the perceived higher rate of crime among African Americans? Or are the criminal justice system, the judicial system, and the juvenile justice system, all together racially biased against Blacks, especially, Black males? How else could criminologists explain the fact that Blacks make up about 12 percent of the population (both men and women), but make up about 50 percent of inmates in jails and prisons across the United States?

Among all the deviant theories, social control theory incorporates three factors, family, school, and peers, which are very important in the study of crime among African Americans. The family is the first agent of socialization that is supposed to prepare a child for subsequent socialization with the outside world. No matter how one looks at the family, it has either a positive influence or a negative influence on the life of a child. Few people today would dispute the fact that the Black family has virtually been destroyed.

School is another agent of socialization that helps to prepare a child for interaction and socialization in the society. Despite the study by Cernkovich and Giordiano (1992) that Blacks bonded well to school just like White students, Fordham and Ogbu (1986), McAdoo and McAdoo (1985), McAdoo (1988b), and Ogbu (1988), believed that Blacks do not bond to school as well as White students. Also, the involvement of Black youth in gangs could be due to several factors that may include peer attachment. Research has shown that gang membership could start as early as age 9 in some cases, and that while 5 percent of all youth have been a gang member by age 15, for blacks, 20 percent have entered a gang by age 15 . Since research has shown that gang membership is associated with higher levels of delinquency, the higher gang membership of black youth could help explain their higher delinquency rate (Gordon, 2004).

Given that the family influences youth deviant behaviors one way or another, nowhere is this truer than among African American families. Even though Hirschi (1969) did not mention attachment to religious beliefs per se, as part of the social control factors in dissuading youth from delinquency, early African American criminologist, Frazier (1949a) viewed the family and other community institutions, such as the church, as agents of social control especially 
for African Americans. The importance of the family in social control is found in his ecological research in Chicago and Harlem.

But since the time of Frazier (1949), the African American family has metamorphosized into mainly single-parent households, usually headed by females. The two-parent stable African American family of the past is fast disappearing into oblivion. According to Smith et al., (1997), single-parent households have increased 543\% among African American families compared to $280 \%$ among White families. This may be due to divorce, births out of wedlock, or incarceration of the father figures. Kunjufu (2000) noted that Black men make up the majority of inmates in jails and prisons in the United States. This supports the view that many Black adolescent males are left in homes without a good role model biological father, or a good role model father figure.

Consequently, in situations where there is no parent, especially, father-child bonding, many African American adolescent males are so overwhelmed with stress and confusion that they engage in deviant behaviors. There is a point in the psychological development of every child when that father-child bonding is so crucial, and if there is no father figure to bond to at that time, this could create a void in the life of the child. This has been found to be true in the lives of many African American adolescent males. They end up having an attitude that nobody wants them, and they are angry and aggressive in their pain of the deprivation of a positive male figure.

Hence, the Black male youth keep searching for alternate solutions to fill the void of a father who was never there for them (Sutton, 2008). The social control theory as expounded by Hirschi (1969) is relevant in the study of crime among African American families. Research has shown that strong bonding to family, school, and peers, could have a protective factor against delinquency. Even though Hirschi (1969) did not mention attachment to religious beliefs as part of social control, but for the African American families, the church could play a significant role in helping to cement the bond of adolescents to their families. Any study of the African American family is not complete without the church. According to Work (1900), in all social study of the Negro, the church must be considered, for it is one of the greatest factors in his social life. It is not only the religious, but also the moral, intellectual, and social center of his community. When the church removes from a district inhabited by Negroes, nothing else comes in to take its place. The church was important to Negroes; it was an integral part of Negro life. The church could be the missing bonding link for attachment to family for many African American youth.

\section{References}

Adlaf, E., \& F. Ivis. (1997). Structure and relations: The influence of familial factors on adolescent substance use and delinquency. Journal of Child and Adolescent Substance Abuse, 5, 1-19. https://doi.org/10.1300/J029v05n03_01

Baumrind, D. (1991). Effective parenting during the early adolescent transition. In Cowan, P. E. and Hetherington, E. M. (eds.), Advances in family research. Erlbaum, Hillsdale, NJ, 
pp. 111-163.

Biron, L., \& M. LeBlanc. (1977). Family components and home-based delinquency. British $\begin{array}{lllll}\text { Journal of } & \text { Criminology, } & 17, & 157-168 .\end{array}$ https://doi.org/10.1093/oxfordjournals.bjc.a046805

Burt, C. (1925). The young delinquent. London: University of London Press.

Cernkovich, S. A., \& P. C. Giordano. (1987). Family relationships and delinquency. Criminology, 25, 295-319. https://doi.org/10.1111/j.1745-9125.1987.tb00799.x

Cernkovich, S. A., \& P. C. Giordano. (1992). School bonding, race, and delinquency. Criminology, 30(2), 261-290. https://doi.org/10.1111/j.1745-9125.1992.tb01105.x

Chapman, S. F. (1991). Attachment and adolescent adjustment to parental remarriage. Family Relations, 40, 232-237. https://doi.org/10.2307/585487

Chen, Z. Y., \& H. B. Kaplan. (1997). The impact of family structure during adolescence ondeviance in early adulthood. Deviant behavior: An Interdisciplinary Journal, 18, 365-391. https://doi.org/10.1080/01639625.1997.9968067

Clayton, R. R., \& H. L. Voss. (1981). Young men and drugs in Manhattan: A causal analysis. NIDA Research Monograph No 39. Washington, DC: Government Printing Office.

Demuth, S., \& S. L. Brown. (2004 February). Family structure, family processes, and adolescent delinquency: The significance of parental absence versus parental gender. Journal of Research in Crime and Delinquency, 41(1), 58-81. https://doi.org/10.1177/0022427803256236

Dornbusch, S. M. (1994). Over-time changes in adjustment and competence among adolescents from authoritative, authoritarian, indulgent, and neglected families. Child Development, 65, 754-770. https://doi.org/10.2307/1131416

Fordham, S. (1988 February). Racelessness as a factor in black students' school success: Pragmatic strategy or pyrrhic victory? Harvard Educational Review, 38, 54-84. https://doi.org/10.17763/haer.58.1.c5r77323145r7831

Fordham, S., \& J. U. Ogbu. (1986). Black students' school success: Coping with the "burden of acting white." The Urban Review, 18(3), 176-206. https://doi.org/10.1007/BF01112192

Frazier, E. F. (1949a). Crime and delinquency: The Negro in the United States. New York: Macmillan Company.

Furstenberg, F. F. Jr. (1987). The new extended family: The experience of parents and children after remarriage. In B. Kay Pasley and Marilyn Ihinger-Tallman (eds.), Remarriage and stepparenting: Current research and theory. New York: Guilford Press.

Goetting, A. (1994). The parenting-crime connection. The Journal of Primary Prevention, 14(3), 169-186. https://doi.org/10.1007/BF01324591 


\section{I Macrothink}

Goodenow, C., \& K. E. Grady. (1993). The relationship of school belonging and friends' values to academic motivation among urban adolescent students. Journal of Experimental Education, 62, 60-71. https://doi.org/10.1080/00220973.1993.9943831

Gottfredson, G. D. (1986). An empirical test of school-based environmental and individual intervention to reduce the risk of delinquent behavior. Criminology, 24, 705-730. https://doi.org/10.1111/j.1745-9125.1986.tb01508.x

Gove, W. R., \& R. D. Crutchfield. (1982). The family and juvenile delinquency. The Sociological Quarterly, 301-319. https://doi.org/10.1111/j.1533-8525.1982.tb01014.x

Hawkins, J. D., \& J. G. Weis. (1985). The social development model: An integrated approach to delinquency prevention. Journal of Primary Prevention, 6, 73-97. https://doi.org/10.1007/BF01325432

Hawkins, J. D., H. J. Doneck., D. M. Lishner. (1988). Changing teaching practices in mainstream classrooms to improve bonding and behavior of low achievers. American Educational Research Journal, 25(1), 31-50. https://doi.org/10.3102/00028312025001031

Hawkins, J. D., \& R, F. Catalano. (1990). Broadening the vision of education: Schools as health promoting environments. Journal of School Health, 60(4), 178-181. https://doi.org/10.1111/j.1746-1561.1990.tb05433.x

Hetherington, E. M. (1987). Family relations six years after divorce. In K. Pasley and M. Ihinger-Tallman (eds.), Remarriage and stepparenting: Current research and theory. New York: Guilford Press.

Hirschi, T. (1969). Causes of delinquency. University of California Press, Berkeley.

Jessor, R, (1982 May). Problem behavior and developmental transition in adolescence. The Journal of School Health, 295-300. https://doi.org/10.1111/j.1746-1561.1982.tb04626.x

Johnson, R. E. (1986). Family structure and delinquency: General patterns and gender $\begin{array}{llll}\text { differences. } & \text { Criminology, } & \text { 65-84. }\end{array}$ https://doi.org/10.1111/j.1745-9125.1986.tb00377.x

Kumpfer, K. L., \& C. W. Turner. (1991). The social ecology model of adolescent substance abuse: Implications for prevention. The International Journal of the Addictions, 25(4A), 435-563.

Lamborn, S. D., N. S. Mounts., L. Steinberg., and S. M. Dornbusch. (1991). Patterns of competence and adjustment among adolescents from authoritative, authoritarian, indulgent, and neglected homes. Child Development, 62, 1049-65. https://doi.org/10.2307/1131151

Liska, A. E., \& M. D. Reed. (1985 August). Ties to conventional institutions and delinquency: Estimating reciprocal effects. American Sociological Review, 50, 547-560. 
https://doi.org/10.2307/2095438

McLanahan, S. S., \& G. Sandefur. (1994). Growing up with a single parent: What hurts, what helps? Cambridge, MA: Harvard University Press.

Matsueda, R. L., \& K. Heimer. (1987 December). Race, family structure, and delinquency: A test of differential association and social control theories. American Sociological Review, 52, 826-840. https://doi.org/10.2307/2095837

McAdoo, H. P. (ed.) (1988a). Black families (2nd Ed.). Newberry Park, CA: Sage.

McAdoo, H. P. (ed.) (1988b). Transgenerational patterns of upward mobility in African American families. In Harriette Pipes McAdoo (ed.), Black families ( $2^{\text {nd }}$ ed.). Newberry Park, CA: Sage.

McAdoo, H. P., \& J. L. McAdoo. (1985). Black children: Social, educational, and parental environments. Newberry Park, CA: Sage.

McBride, C. M., S. J. Curry., A. Cheadle., C. Anderson., E. H. Wagner., P. Diehr., \& B. Psaty. (1995). School-level application of a social bonding model to adolescent risk-taking behavior. Journal of School Health, 65(2), 63-68. https://doi.org/10.1111/j.1746-1561.1995.tb03347.x

Nye, F. I. (1958). Family relationships and delinquent behavior. New York: John Wiley and Sons.

Ogbu, J. U. (1988). Black education: A cultural-ecological perspective. In Harriete Pipes McAdoo. (ed.), Black families ( $2^{\text {nd }}$ ed.). Newberry Park, CA: Sage.

Paulson, S. E. (1994). Relations of parenting style and parental involvement with ninth-grade students' achievement. Journal of Early Adolescence, 14(2), 268-291. https://doi.org/10.1177/027243169401400208

Perry, C. A., \& R. Jessor. (1984). The concept of health promotion and the prevention of adolescent drug use. Health Education Quarterly, 12, 169-184. https://doi.org/10.1177/109019818501200204

Pianta, R. C., \& S. Nimetz. (1991). Relationships between children and teachers: Associations with home and classroom behavior. Journal of Applied Developmental Psychology, 12, 379-393. https://doi.org/10.1016/0193-3973(91)90007-Q

Polk, K., C. Adler., G. Bazermore., G. Blake., S Cordray., G. Coventry., J. Galvin., and M. Temple. (1981). Becoming adult: An analysis of maturational development from age 16 to 30 of a cohort of young men. Final Report of the Marion County Youth Study. Eugene: University of Oregon.

Pyper, J. R., H. J. Freiberg., M. Ginsburg., D. W. Spuck. (1987). Instrument to measure school climate. In Barber, L. W. (ed.), School climate. Bloomington Center on Evaluation. Phi Delta Kappa, pp.87-96. 
Rankin, J. H., \& R. Kern. (1994). Parental attachments and delinquency. Criminology, 32, 495-515. https://doi.org/10.1111/j.1745-9125.1994.tb01163.x

Rosenbaum, J. L., \& J. R. Lasley. (1990 September). School, community context, and delinquency: Rethinking the gender gap. Justice Quarterly, 7, 493-513. https://doi.org/10.1080/07418829000090701

Shaw, C. R., \& H. D. McKay. (1932). Are broken homes a causative factor in juvenile delinquency? Social Forces, 10, 514-24. https://doi.org/10.2307/2569899

Schaps, E., \& V. Battistich. (1991). Promoting health development through school-based prevention: New approaches. In Goplerud, E. N. (ed.). Preventing adolescent drug use: From theory to practice. Office for Substance Abuse Prevention Monograph 8, USDHHS, PHS, ADAMHA, Rockville, MD, pp. 127-181.

Siegel, L. J., \& J. J. Senna. (1988). Juvenile delinquency: Theory, practice, and law (3 ${ }^{\text {rd }}$ ed.). St. Paul, Minn: West.

Simons-Morton, B. G., A. D. Crump., D. L. Haynie., \& K. E. Saylor. (1999). Student-school bonding and adolescent problem behavior. Health Education Research, 14(1), 99-107. https://doi.org/10.1093/her/14.1.99

Slawson, J. (1926). The delinquent boy. Boston, MA: Badger.

Steinberg, L. (1993). Adolescence. New York: McGraw-Hill.

Sutton, R. M. (2008 May). African American adolescent males' involvement in the juvenile justice system: An exploratory analysis. Dissertation, Howard University.

Thornberry, T., M. Moore., and R. L. Christenson. (1985 February). The effects of dropping out of high school on subsequent criminal behavior. Criminology, 23, 3-18. https://doi.org/10.1111/j.1745-9125.1985.tb00323.x

Van Voorhis, P., F. T. Cullen., R. A. Mathers., and C. C. Garner. (1988). The impact of family structure and quality on delinquency: A comparative assessment of structural and $\begin{array}{llll}\text { functional factors. } & \text { Criminolgy, 235-61. }\end{array}$ https://doi.org/10.1111/j.1745-9125.1988.tb00840.x

Wells, E. L., \& J. H. Rankin. (1991). Families and delinquency: A meta-analysis of the impact of broken homes. Social Problems, 38(1), 71-93. https://doi.org/10.2307/800639

Wentzel, K. (1997). Student motivation in middle school: The role of perceived pedagogical

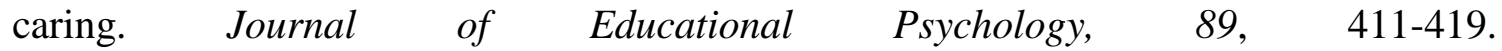
https://doi.org/10.1037/0022-0663.89.3.411

White, L. K., D. D. Brinkerhoff, and A. Booth. (1985). The effect of marital disruption on child's attachment to parents. Journal of Family Issues, 6, 5-22. https://doi.org/10.1177/019251385006001002

Work, M. (1900). Crime among the Negroes of Chicago. American Journal of Sociology, 6, 
204-223. https://doi.org/10.1086/210962

\section{Copyright Disclaimer}

Copyright for this article is retained by the author(s), with first publication rights granted to the journal.

This is an open-access article distributed under the terms and conditions of the Creative Commons Attribution license (http://creativecommons.org/licenses/by/3.0/). 